ZOOLOGIA 31 (6): 639-643, December, 2014

http://dx.doi.org/10.1590/S1984-46702014000600010

\title{
Three new species of Hydroptila (Trichoptera: Hydroptilidae) from Northeastern Brazil
}

\author{
Wagner Rafael M. de Souza ${ }^{1,2}$, Allan Paulo Moreira Santos ${ }^{1} \&$ Daniela Maeda Takiya ${ }^{1}$
}

\author{
${ }^{1}$ Laboratório de Entomologia, Departamento de Zoologia, Instituto de Biologia, Universidade Federal do Rio de Janeiro. \\ Caixa Postal 68044, 21941-971 Rio de Janeiro, RJ, Brazil. \\ 2 Corresponding author, E-mail: faelwagner@gmail.com
}

\begin{abstract}
Hydroptila Dalman, 1819 is one of the most diverse genus of Hydroptilidae, comprising over 400 species distributed in all biogeographical regions. Only two species were previously recorded from Brazil. Here, three new species from Northeastern Brazil are described and illustrated. The new species can be distinguished based on the male genitalia: Hydroptila marighellai sp. nov. can be recognized by the pliers-shaped tergum X; H. florestani sp. nov. can be recognized by having inferior appendages curved upwards in lateral view; and $H$. zerbinae sp. nov. differs from the other species of the denza group in the apex of the tergum $\mathrm{X}$, which is wide in lateral view, and the undivided apical portion of the phallus. These are the first records of species of Hydroptila from Northeastern Brazil.
\end{abstract}

KEY WORDS. Hydroptilinae; microcaddisfly; Neotropical Region; taxonomy.

Hydroptila Dalman, 1819 is the most speciose genus of microcaddisflies. It comprises over 400 species, which are widely distributed (Marshall 1979, Harris \& Holzenthal 1999, Morse 2014). Marshall (1979) recognized 13 geographically distinct species groups based on the structure of the male genitalia, but many species have been described since her revision most of which were not placed in any group. Currently, about 60 species have been described from the Neotropical Region, many by Bueno-Soria (1984) and Harris \& Holzenthal (1999). In Brazil, only two species have been recorded so far: Hydroptila argentinica Flint, 1983 and $H$. producta Mosely, 1939, both occurring in the Southern and Southeastern regions (Mosely 1939, FuINT 1983, Dumas et al. 2009).

Ross (1944) and Wiggins (1996) described larvae and pupae of a few Hydroptila species. Fifth-instar larvae can be recognized by the three apical abdominal gills, which are lost in the prepupal stage (WIGGINs 1996). As typical for Hydroptilidae, the larva builds a case immediately before the final instar. Larval cases have two compressed valves, usually covered with a layer of sand grains and lined internally with a silken web (Nielsen 1948).

Three new species of Hydroptila are described and illustrated. They represent the first record of species of this genus from Northeastern Brazil. The new species are named in memory of the $50^{\text {th }}$ anniversary of the Military Coup in Brazil. They are named after leaders of the resistance to the military dictatorship.

\section{MATERIAL AND METHODS}

Specimens were collected using Pennsylvania light (Frost 1957) and Malaise traps (Gressit \& Gressit 1962) in the states of Alagoas, Bahia, Ceará, Pernambuco, and Piauí, Northeastern Brazil, and preserved in 96\% ethanol. For the study of genital structures, the abdomen was removed and cleared in a heated solution of $10 \% \mathrm{KOH}$. Pencil sketches were made using a compound microscope (Carl Zeiss, Model Axiolab). Sketches were used as templates for tracing graphic vectors in Adobe Illustrator ${ }^{\circledR}$, version 5.1. Species descriptions were made using DELTA software - Descriptive Language for Taxonomy (DALlwitz et al. 1999). Lists of material examined were made using AUTOMATEX macro (BRown 2013). Terminology follows that of Marshall (1979).

Type specimens are deposited at the following institutions: Coleção Zoológica do Maranhão, Universidade Estadual do Maranhão, Caxias (CZMA); Coleção Entomológica Professor José Alfredo Pinheiro Dutra, Departamento de Zoologia, Universidade Federal do Rio de Janeiro, Rio de Janeiro (DZRJ); Museu de Zoologia da Universidade Federal da Bahia, Salvador (MZUFBA), and Coleção Entomológica da Universidade Federal de Pernambuco, Departamento de Zoologia, Universidade Federal de Pernambuco, Recife (CE-UFPE).

\footnotetext{
* The Editorial Board of Zoologia has evaluated only the scientific aspects of this paper. The authors are entirely responsible for the names chosen for the new species.
}

2014 Sociedade Brasileira de Zoologia | www.sbzoologia.org.br | www.scielo.br/zool All content of the journal, except where identified, is licensed under a Creative Commons attribution-type BY-NC. 


\section{TAXONOMY}

\section{Hydroptila marighellai sp. nov. \\ Figs 1-4}

Description. Holotype. Adult male. Body length (from tip of head to wing apex): $2.2 \mathrm{~mm}$. General color: uniform brown (in alcohol). Head with small scent caps. Antennae simple, 35-articulated. Ocelli absent. Maxillary palpi 5-articulated. Labial palpi 3-articulated. Tibial spur formula 0, 2, 4 . Venation of anterior wing distinct, veins reaching wing margin. Posterior wing with venation distinct; with long setae on anal margin. Mesoscutellum without transverse suture. Metascutellum subtriangular. Abdomen without visible modifications. Segment VII with a mesoventral process (Fig. 1).

Male genitalia. Segment VIII (Figs 1 and 3) annular. Segment IX with tergum reduced to a protruding lobe in dorsal view (Fig. 2); sternum with posterior margin concave (Fig. 1); with ventrolateral process directed posteriorly in lateral view, slightly curved inward in dorsal view (Fig. 3). Inferior appendages, in lateral view, narrow at base, widening distally with posterior margin truncate (Fig. 3); in ventral view, narrower at base than at apex, distal portion club-shaped, and apex slightly projected with a dark spot (Fig. 1). Subgenital plate rounded at apex, large, and with a pair of small setae apically (Fig. 1). Tergum X broad, mesally divided; distal portion pliers-shaped with posterior margin slightly emarginate in dorsal view (Fig. 2); in lateral view, rectangular with posterior margin truncate and dorsal margin slightly sclerotized (Fig. 3). Phallus with tubular basal portion, distal portion narrowing apically; with an apical sclerotized process sharply bent laterally (Fig. 4); paramere encircling shaft in median area; ejaculatory duct protruding apically (Fig. 4).

Female and immature stages unknown.

Remarks. Hydroptila marighellai sp. nov. is similar to $H$. pulestoni Flint, 1980, but can be distinguished by the shape of the inferior appendages in lateral view, phallus, and tergum X. Inferior appendages of both species are similar in ventral view, but in lateral view the narrow base and the subrectangular apical region of $H$. marighellai sp. nov are distinctive. In addition, although the phallus in both species has a similar sharply angled apex, the paramere is shorter and crosses the distal part in the new species. The more distinctive characteristic, which distinguishes $H$. marighellai sp. nov. from $H$. pulestoni and other Hydroptila species, is the pliers-shaped tergum X.

Holotype. 1 male, BraziL: Ceará: Parque Nacional de Ubajara (Rio das Minas próximo ao teleférico, $03^{\circ} 48^{\prime} 58^{\prime \prime} \mathrm{S}, 40^{\circ} 53^{\prime} 53^{\prime \prime} \mathrm{W}$, 420 m, 20-23.iii.2013), D.M. Takiya, F. Limeira-de-Oliveira, and J.A. Rafael leg., Malaise trap (CZMA). Paratypes. BrazIL: Alagoas: Reserva Biológica de Pedra Talhada (Rio Caranguejo, 09¹5'26"S, $\left.36^{\circ} 25^{\prime} 54^{\prime \prime} \mathrm{W}, 661 \mathrm{~m}\right), 1$ male, 28.viii.2013, L.R.C. Lima, J. Lira, and J. Sandes leg., light trap (CE-UFPE 300029); Ceará: Parque Nacional de Ubajara (Rio das Minas, trilha Araticum, 03 50'03"S, $\left.40^{\circ} 54^{\prime} 18^{\prime \prime} \mathrm{W}, 524 \mathrm{~m}\right), 2$ males, 22.iv.2012, D.M. Takiya, R.R. Cavichioli leg., Pennsylvania trap (DZRJ); Pernambuco: Amaraji
(Barragem Jaguarana, $\left.08^{\circ} 21^{\prime} 01^{\prime \prime} \mathrm{S}, 34^{\circ} 24^{\prime} 27^{\prime \prime} \mathrm{W}\right), 1$ male, 5.xii.2012, L.R.C. Lima leg., Pennsylvania trap (CE-UFPE 300030).

Etymology. This species is named in honor of Carlos Marighella, founder of the "Ação Libertadora Nacional", an movement of opposition to the Brazilian Military Government (1964-1985).

\section{Hydroptila florestani sp. nov. Figs 5-10}

Description. Holotype. Adult male. Body length (from tip of head to wing apex): $2.1 \mathrm{~mm}$. General color: pale yellow (in alcohol). Head with small scent caps. Antennae simple, yellow; 32-articulated. Ocelli absent. Maxillary palpi 5-articulated. Labial palpi 3-articulated. Tibial spur formula 0, 2, 4. Venation of anterior wing distinct, veins reaching wing margin. Posterior wing with venation distinct; with long setae on anal margin. Mesoscutellum without transverse suture. Metascutellum subtriangular. Abdomen without visible modifications. Segment VII with a mesoventral process (Fig. 5).

Male genitalia. Segment VIII annular (Figs 5 and 7). Segment IX with tergum short, with posterior margin protruding and rounded in dorsal view, distal portion darkened (Fig. 6); sternum with posterior margin concave in ventral view (Fig. 5); with ventrolateral process directed posteriorly in lateral view (Fig. 7). Inferior appendages, in lateral view, slightly curved upwards with dark spot at apex, and a few small setae (Fig. 7); in ventral view, slender, curved outerad, with approximately same width throughout (Fig. 5). Subgenital plate broad and rounded with pair of small setae apically (Fig. 5). Tergum X slightly sclerotized, base rectangular, distal portion membranous, with margin irregularly emarginate (Fig. 6); oblong and extending posteriorly as far as inferior appendage in lateral view (Fig. 7). Phallus with tubular basal portion, distal portion narrow (Fig. 8); apical process abruptly bent laterally, with acute tip in lateral view (Fig. 9); paramere encircling shaft basad to junction of basal and distal portion, crossing the distal portion (Fig. 8); ejaculatory duct protruding, with median region curved (Fig. 8).

Female and immature stages unknown.

Remarks. Hydroptila florestani sp. nov. shares some characteristics of the male genitalia with $H$. potosina Bueno-Soria, 1984 and $H$. arctia Ross, 1938. The general aspect of the inferior appendages in ventral view and the curved phallus apex are very similar in these three species. However, $H$. florestani sp. nov. can be recognized by having tergum $\mathrm{X}$ irregularly emarginate posteriorly, inferior appendages slender and curved outward in dorsal view, and ventrolateral process of segment IX shorter.

Intraspecific variation. Some individuals of this species have the apical process of the phallus not abruptly bent in dorsal view (Fig. 10) as described for the holotype (Figs 8 and 9).

Holotype. 1 male, Brazil, Piauí: Parque Nacional de Sete

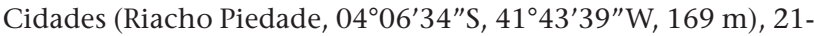
24.iv.2012, D.M. Takiya, F. Limeira-de-Oliveira, and J.A. Rafael leg., Malaise trap (CZMA). Paratypes. BrazIL, Piauí: same data as 


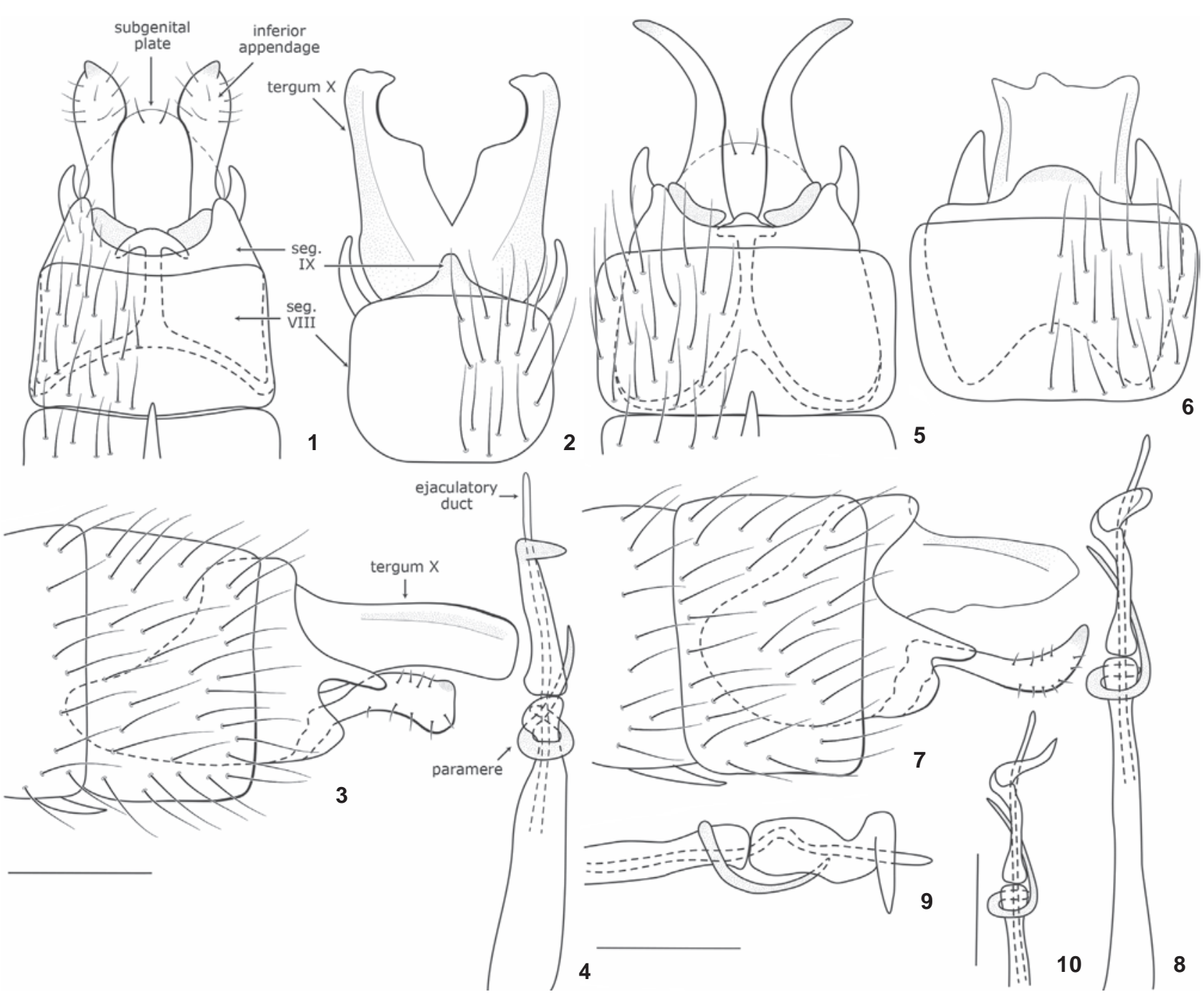

Figures 1-10. (1-4) Hydroptila marighellai sp. nov., male genitalia: (1) ventral; (2) dorsal; (3) left lateral; (4) phallus, dorsal. (5-10) Hydroptila florestani sp. nov., male genitalia: (5) ventral; (6) dorsal; (7) left lateral; (8) phallus, dorsal; (9) phallus, left view; (10) phallus variation, dorsal. Scale bar: $0.1 \mathrm{~mm}$.

holotype, 2 males (CZMA); same data as holotype, 2 males, except 19.iv.2012, D.M. Takiya leg., Pennsylvania trap (DZRJ).

Etymology. This species is named in honor of the sociologist Florestan Fernandes, who published many texts opposing the Brazilian Military Government and coordinated the "Escola Paulista de Sociologia" from 1964 to 1969.

\section{Hydroptila zerbinae sp. nov.}

\section{Figs 11-14}

Description. Holotype. Adult male. Body length (from tip of head to wing apex): $2.2 \mathrm{~mm}$. General color: uniform brown (in alcohol). Head with small scent caps. Antennae simple, yellow; 35-articulated. Ocelli absent. Maxillary palpi 5-articulated. Labial palpi 3-articulated. Tibial spur formula 0, 2 , 4. Venation of anterior wing distinct, veins reaching wing margin. Posterior wing with venation distinct; with long setae on anal margin. Mesoscutellum without transverse suture. Metascutellum subtriangular. Abdomen without visible modifications. Segment VII with a mesoventral process (Fig. 11).

Male genitalia. Segment VIII annular (Figs 11 and 13). Segment IX with tergum short, subtriangular and rounded apically (Fig. 12); sternum with posterior margin concave; with ventrolateral process straight in lateral view (Fig. 13). Inferior appendages, in lateral view, narrow at base, with mesal region dilated; apex directed upwards, with dark spot apically (Fig. 13); with few small setae; straight with divergent apex in ven- 

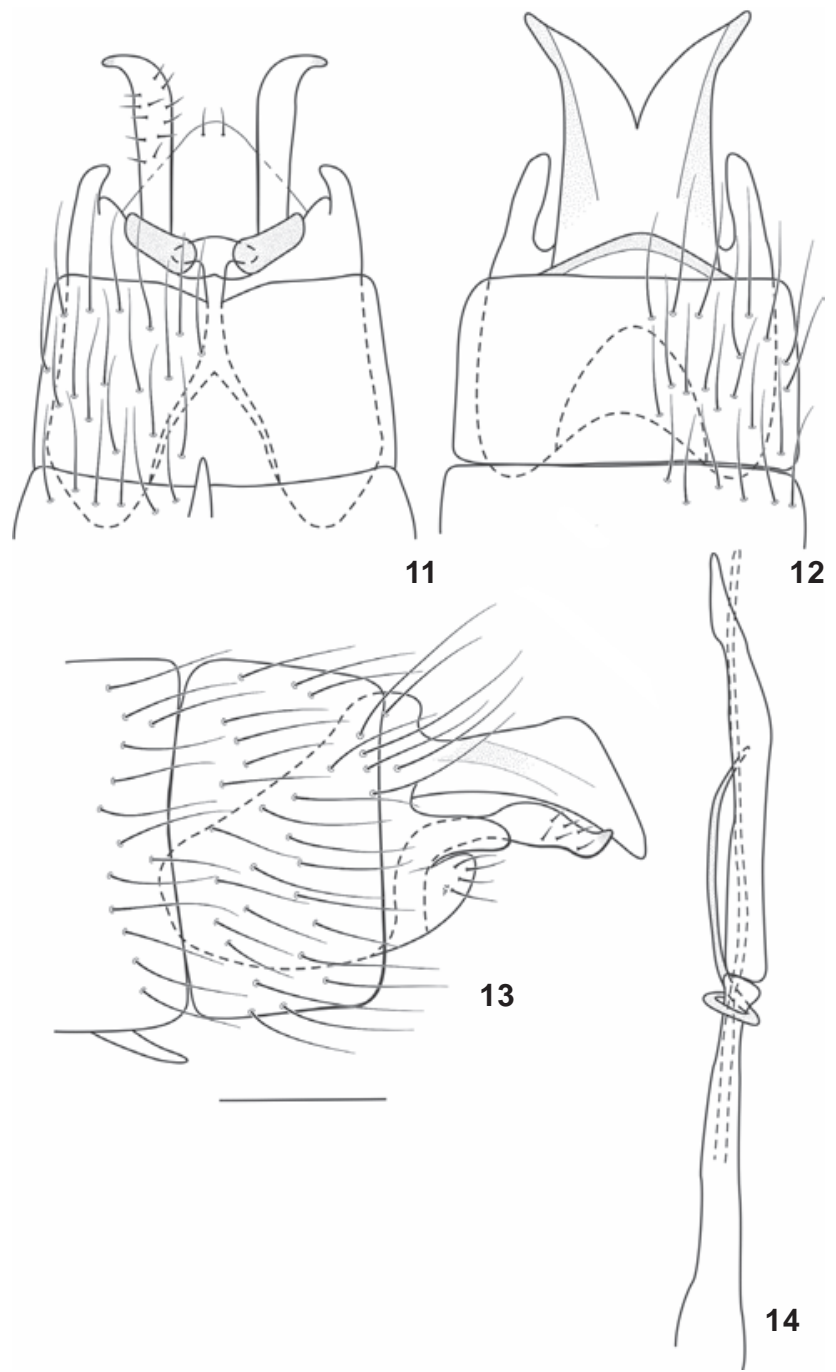

Figures 11-14. Hydroptila zerbinae sp. nov., male genitalia: (11) ventral; (12) dorsal; (13) left lateral; (14) phallus, dorsolateral. Scale bar: $0.1 \mathrm{~mm}$.

tral view (Fig. 11). Subgenital plate triangular with apex rounded and a pair of small setae apically (Fig. 11). Tergum X broad basally, lateral margin concave at mid-length and slightly sclerotized, divided mesally (Fig. 12); subrectangular, narrow at base, widening apically, with posterior margin broad in lateral view (Fig. 13). Phallus with tubular basal portion, distal portion narrowing distally; apex acute and not bent; paramere encircling shaft, but not crossing its distal portion; ejaculatory duct protruding, extending posteriorly to apex of phallus.

Female and immature stages unknown.

Remarks. Based on the overall aspect of the male genitalia, this species is clearly a member of the denza group. Hydroptila zerbinae sp. nov. resembles H. osa Harris \& Holzenthal, 1999 in the shape of tergum $\mathrm{X}$, which has a deep mesal incision posteriorly, and resembles $H$. paradenza Harris \& Holzenthal, 1999 and $H$. denza Ross, 1948 in the shape of the inferior appendages. From these species, $H$. zerbinae sp. nov. differs in having tergum $\mathrm{X}$ wide apically in lateral view, and apical portion of phallus not divided as in H. osa. Harris \& Holzenthal (1999) provided a valuable discussion on the Hydroptila denza group, and suggested that distributional information could be useful to separate the included species. Among the members of this group, only $H$. grenadensis has been recorded from South America, and from this species, $H$. zerbinae sp. nov. can be easily distinguished by the shape of the inferior appendages, straight with divergent apices, and the shape of tergum $\mathrm{X}$. The new species is the first one of the denza group recorded from Brazil.

Holotype. 1 male, Brazil, Pernambuco: Vicência (Cachoeira do Engenho Embú, 07³7'22"S, 35²2'51"W, 186 m), 13.xi.2011, L.R.C. Lima and W.R. M. Souza leg., Pennsylvania trap (DZRJ). Paratypes. Brazil, Alagoas: Reserva Biológica de Pedra Talhada (09¹5'26"S, 36²5'54”W, $661 \mathrm{~m}), 1$ male, 28.vii.2013, L.R.C. Lima, J. Lira, and J. Sandes leg., light trap (CE-UFPE 300031); Bahia: Camacan (Fazenda Waldemar Farmácia, abaixo da represa de abastecimento, $\left.15^{\circ} 25^{\prime} 16^{\prime \prime} \mathrm{S}, 39^{\circ} 33^{\prime} 67^{\prime \prime} \mathrm{W}, 300 \mathrm{~m}\right), 6$ males, 5.viii.2008, A.R. Calor leg., light trap (MZUFBA); Camacan (Fazenda Waldemar Farmácia, acima da represa de abastecimento, $\left.15^{\circ} 25^{\prime} 17^{\prime \prime} \mathrm{S}, 39^{\circ} 34^{\prime} 0,2^{\prime \prime} \mathrm{W}, 310 \mathrm{~m}\right), 3$ males, 5.viii.2008, A.R. Calor leg., light trap (MZUFBA); Camacan (Rio Panelão em frente

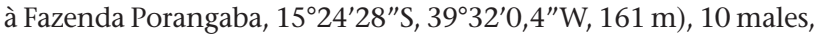
1.iii.2012, D.M. Takiya leg., light trap (DZRJ); Pernambuco: Amaraji (Barragem Jaguarana, $\left.08^{\circ} 21^{\prime} 01^{\prime \prime} \mathrm{S}, 34^{\circ} 24^{\prime} 27^{\prime \prime} \mathrm{W}\right), 1$ male, 5.xii.2012, L.R.C. Lima leg., Pennsylvania trap (CE-UFPE 300032); Amaraji (Rio Amaraji próximo à usina, $8^{\circ} 21^{\prime} 48,9^{\prime \prime} \mathrm{S}, 35^{\circ} 28^{\prime} 49^{\prime \prime} \mathrm{W}$, 320 m), 1 male, 11.v.2013, L.R.C. Lima leg., light trap (CE-UFPE 300033); Orobó (Cachoeira Poço Verde, 0744'10"S, 35³2'35"W, 242 m), 13 males, 28.ix.2012, L.R.C. Lima and W.R. M. Souzaleg. (CE-UFPE 300034); same data as holotype, 5 males (DZRJ).

Etymology. This species is named after Therezinha de Godoy Zerbini who organized the "Movimento Feminino Pela Anistia" in many Brazilian States.

\section{ACKNOWLEDGMENTS}

WRMS is grateful to Coordenação de Aperfeiçoamento de Pessoal de Nível Superior (CAPES) and Fundação de Amparo à Ciência e Tecnologia do Estado de Pernambuco (FACEPE) for M.Sc. and undergraduate fellowships, respectively. We thank Conselho Nacional de Desenvolvimento Científico e Tecnológico (CNPq, PROTAX proc. 562.303/2010-3) for financial support to DMT and Instituto Chico Mendes de Conservação da Biodiversidade (ICMBio) for collecting permits. Field trips to PN Ubajara and Sete Cidades were possible thanks to a project funded by CNPq/ICMBio program "Pesquisa em Unidades de Conservação do Bioma Caatinga", which is coordinated by J.A. Rafael (INPA, proc. 551991/2011-9). We are thankful to the following individu- 
als for collecting and loaning specimens: A.R. Calor (MZUFBA), Lucas Lima (UESPI), Joana Sandes, and Juliana Lira (UFPE).

\section{LITERATURE CITED}

Bueno-SoRIA, J. 1984. Estudios en insectos acuaticos II. Revision para Mexico e Centroamerica del gênero Hydroptila Dalman, 1819 (Trichoptera: Hydroptilidae). Folia Entomológica Mexicana 59: 79 -138.

Brown, V.B. 2013. Automating the "Material Examined" section of taxonomy papers to speed up species descriptions. Zootaxa 3683 (3): 297-299. doi: 10.11646/zootaxa.3683.3.8

Dalman, J.W. 1819. Nagra nya insekt-genera, beskrifina. Kongliga Vetenskap-Akadamiens Handlingar 40: 117-127.

Dallwitz, M.L.; T.A. Paine \& E.J. Zucher. 1999. User's guide to DELTA Editor. Available online at: https://code.google.com/ p/open-delta [Accessed: 16/VII/2014]

Dumas, L.L.; G.A. Jardim; A.P.M. Santos \& J.L. Nessimian. 2009. Tricópteros (Insecta: Trichoptera) do Estado do Rio de Janeiro: Lista de espécies e novos registros. Arquivos do Museu Nacional 67: 355-376.

Fuint JR, O.S. 1980. Studies of the Neotropical Caddisflies, XXVI: New species from Argentina (Trichoptera). Revista de la Sociedad Entomológica Argentina 39: 137-142.

FLINT JR, O.S. 1983. Studies in Neotropical Caddisflies, XXXIII: new species from Austral South America (Trichoptera). Smithsonian Contributions to Zoology 377: 1-100.
Frost, S.W. 1957. The Pennsylvania insect light trap. Journal of Economic Entomology 9: 52-172.

Gressit, J.L. \& M.K. Gressit. 1962. An improved Malaise trap. Pacifc Insects 4 (1): 87-90.

HarRis, S.C. \& R.W. Holzenthal. 1999. Hydroptilidae (Trichoptera) of Costa Rica: The genus Hydroptila Dalman. Studies on Neotropical Fauna and Environment 34: 16-54.

Marshall, J.E. 1979. A review of the genera of the Hydroptilidae (Trichoptera). Bulletin of the British Museum (Natural History) Entomology Series 39 (3): 135-239.

Mosely, M.E. 1939. The Brazilian Hydroptilidae (Trichoptera). Novitates Zoologicae 41: 217-239.

Morse, J. 2014. Trichoptera World Checklist. Available online at: http://www.entweb.clemson.edu/database/trichopt [Accessed: 02/VIII/2014]

Nielsen, A. 1948. Postembryonic development and biology of the Hydroptilidae: a contribution to the phylogeny of the caddis flies and to the question of the origin of the casebuilding instinct. Biologiske Skrifter V (1): 1-200.

Ross, H.H. 1938. Descriptions of the Nearctic Caddis Flies (Trichoptera). Bulletin of the Illinois Natural History Survey 21 (4): 101-183.

Ross, H.H. 1944. The caddis flies, or Trichoptera, of Illinois. Bulletin of the Illinois Natural History Survey 23 (1): 1-326.

Wiggins, G.B. 1996. Larvae of the North American Caddisfly Genera (Trichoptera). Toronto, University of Toronto Press, $2^{\text {nd }}$ ed., $457 \mathrm{p}$.

Submitted: 19.VIII.2014; Accepted: 09.IX.2014.

Editorial responsibility: Gabriel L.F. Mejdalani 